\title{
Species Relationships for Plasma Angiotensin Converting Enzyme Activity Using a Furanacryloyl Tripeptide Substrate
}

\author{
G. O. Evans \\ Department of Drug Safety Evaluation, Wellcome Research Laboratories, \\ Beckenham. Kent, BR3 3BS, England.
}

(Received 28 October 1988/Accepted 11 January 1989)

\begin{abstract}
Angiotensin converting enzyme (ACE ; EC 3.4.15.1) activities were compared in plasma samples obtained from three species using a furanacryloyl tripeptide substrate. The enzyme activity observed in Wistar rat plasma was higher than the activities observed in the other two species. Using this substrate, human and canine plasma enzyme activities were similar-unlike published data where hippurylhistidyl-leucine was used as substrate.
\end{abstract}

Serum angiotensin converting enzyme (ACE ; EC 3.4.15.1) activities are reported to vary widely between several mammalian species. Using hippuryl-histidyl-leucine (Hip-HisLeu) substrate at $\mathrm{pH}$ 7.2, Kase et al [1] found the mean value for human sera was approximately $20 \%$ of the mean value obtained for Wistar

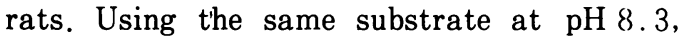
Horiuchi et al [2] found the mean value for Wistar rats was approximately three fold the mean value for human sera, but the mean canine value was approximately one fifth of the value for human sera. Holmes [3] using heparinised plasma and the same substrate confirmed these markedly lower values in canine plasma. Differences have been observed when human plasma samples have been analysed using three substrates [4] ; good correlation was observed between methods using $\mathrm{p}$-hydroxybenzoyl-glycyl-L-histidyl-L-leucine and a furanacryloyl tripeptide, but these two methods correlated poorly with a method using glycylL-histidyl-glycine substrate.

In this study, twenty heparinised plasma samples were obtained from three species. Healthy Wistar rats (8-12 weeks old) and Beagle dogs (8-12 months old) were kept in an air-conditioned and light-controlled environment. The rat blood samples were obtained from the right ventricle following euthanasia with carbon dioxide, and the canine samples were collected from an exterior jugular vein without anaesthesia. Blood samples were also collected from healthy human volunteers. The plasma samples were stored at $-20^{\circ} \mathrm{C}$ and analysed within thirty days of collection.

Plasma ACE activities were determined using a reagent kit containing the substrate 3 (2-furylacryloyl)-L-phenylalanylglycylglycine at pH 8. 2 (Sigma Chemical Company, U. S. A.) and a Roche CobasBio centrifugal analyser at $37^{\circ} \mathrm{C}[5,6]$. The within-assay precision data for this method expressed as coefficient of variation was $4.99 \%$ at an activity of $57 \mathrm{U} / \mathrm{L}$ for a rabbit control serum.

The results confirmed that rat plasma ACE values were markedly higher than human values (Table 1). However, the results for canine samples were similar to those for human samples, in contrast to the published data for methods using Hip-His-Leu substrate. These observations may be due to different substrates, but they may also reflect differing $\mathrm{pH}$ optima, chloride ion dependency and other factors in the determination of ACE activity $[7,8]$. These differences between species do not particularly support the suggestion by Holmes [4] that the Beagle dog is a poor model for testing ACE inhibitors because of low plasma activity obtained with Hip-His-Leu substrate : 
Table 1. Plasma angiotensin converting enzyme activity in three species

\begin{tabular}{lc}
\hline Species & $\begin{array}{c}\text { ACE activity }(\mathrm{U} / \mathrm{L}) \\
\text { Mean } \pm 1 \mathrm{SD}\end{array}$ \\
\hline Man & $41.5 \pm 29.1$ \\
Beagle & $47.5 \pm 8.9$ \\
Wistar Rat & $166.0 \pm 32.9$ \\
\hline & $(\mathrm{n}=20$ for each species $)$
\end{tabular}

the catalytic properties of renal ACE and the potency of some ACE inhibitors are remarkably similar despite the apparent variations of plasma ACE $[9,10]$.

\section{References}

[1] Kase, R., Hazato, T., Kiuchi, Y., and Katayama, T. (1986). Exp. Anim, 35, 107-108.
[2] Horiuchi, M., Fujimura, K-I., Terashima, T., and Iso, T. (1982) . J. Chromat., 233, 123-130

[3] Holmes, S. W. (1987). Br. J. Tharm, 92, 784 P.

[4] Baars, J. D., Lombarts, A. J. P. F., and de Kieviet, W. (1987). Tïdschr Med. Ver. Klin. Chem, 12, 227230 .

[5] Holmquist, B., Bünning, P., and Riordan, J. F.(1979). Anal Biochem, 95, 540-548.

[6] Wong, Y-W and Kinniburgh, D. W. (1987). Clin Biochem, 20, 323-327.

[7] Ondetti, M. A. and Cushman, D. W. (1982). Ann. Rev. Biochem, 51, 294-304.

[8] Evans, G. O. (1988). Clin. Chem, 34, 1523-1524.

[9] Takada, Y., Unno, M., Hiwada, K., and Kokubu, T. (1982). Comp. Biochem Physiol, 73 B , 189-194.

[10] Ho, E. H. and Cantor, E. H. (1987). Clin. Chem, 33 , 893.

$$
\begin{gathered}
\text { フンフクリロール } \quad \text { リペプチド基質を用いた場合の血漿 } \\
\text { アンギオテンシン変換酵素活性にみられる動物種差 } \\
\text { ガレス・オーウェン・エヴァンス } \\
\text { ウェルカム研究所薬物安全性評価部門 }
\end{gathered}
$$

\footnotetext{
フランアクリーロール トリペプチド基質を用い, ア ンギオテンシン変換酵素（ACE；EC 3.4.15.1) 活性 を，3つの動物種より採取した血漿検体において比較し た。Wistar ラット血漿中に認められた酵素活性は他の

2 種における活性よりる高かった。この基質を用いた場 合のヒトとイヌの血漿酵素活性は同程度であり,これれ 既に発表された，ヒプリル・ヒスチジル・ロイシンを基 質として用いた場合のデータとは異なるものであった。
} 